\title{
NUTRIENT CONTENT OF SOME LOCALLY AVAILABLE ORGANIC MATERIALS AND THEIR POTENTIAL AS ALTERNATIVE SOURCES OF NUTRIENTS FOR COCONUT
}

\author{
N. A. Tennakoon and S. D. Hemamala Bandara \\ Coconut Research Institute, Lunuwila, Sri Lanka
}

\begin{abstract}
Fourteen organic materials were collected from five coconut growing areas in Sri Lanka viz. Chilaw, Gampaha, Negombo, Kurunegala, and Kalutara. They were cattle manure, goat manure, broiler and layer poultry manure, pig manure, farm yard manure (FYM), biogas residue, sewage sludge, compost, gliricidia, pueraria, calopagonium, and acacia. Their total $\mathrm{N}, \mathrm{P}, \mathrm{K}, \mathrm{Ca}, \mathrm{Mg}$, $\mathrm{Na}, \mathrm{Fe}, \mathrm{Mn}, \mathrm{Cu}, \mathrm{Zn}, \mathrm{B}, \mathrm{Cd}, \mathrm{NH}_{4}-\mathrm{N}, \mathrm{NO}_{3}-\mathrm{N}$ and organic carbon (OC) contents were determined. The plant materials and animal manures contain appreciable quantities of plant nutrients. Nutrient content of each organic material was found to be variable depending on the origin and location. Goat manure and fresh foliage of gliricidia had a higher content of $\mathrm{N}$, than the other materials. The $\mathrm{N}$ content was higher in broiler than in layer litter. Sewage sludge had the lowest $\mathrm{N}$ content. Highest $\mathrm{P}$ content was in poultry manure, while $K$ content was highest in green materials. Magnesium content was higher in FYM and biogas residue. The materials tested have considerable amounts of macro and micro nutrients and these materials could be used as a source of plant nutrients for coconut, to supply the $N$ requirement in full and $\mathrm{P}, \mathrm{K}$ and $\mathrm{Mg}$ requirements partially.
\end{abstract}

\section{INTRODUCTION}

The coconut growers are showing an interest in utilizing organic manures, primarily due to the exorbitant price of imported chemical fertilizers. Organic materials, such as animal manures, green manures, crop residues, kitchen wastes and sewage sludge are often freely available. Organic wastes serve not only as a source of plant nutrients but also in restoring soil fertility and soil quality, thereby improving the chemical, physical and biological properties of soil (Parr and Colacicco, 1987; Maraikar and Amarasiri 1988; Tennakoon et al; 1995). The benefits of organic manures, for stimulating plant growth and increasing crop yield (Tennakoon, 1990) and developing resistance to pests and diseases (Flaig, 1984) have also been reported. The aim of this study is to determine the macro and micro nutrient contents of some locally available organic materials, which could be used as manure for coconut, and to assess their nutritional value. 


\section{MATERIALS AND METHODS}

Fourteen different kinds of organic materials were collected from five coconut growing areas in Sri Lanka viz. Chilaw, Gampaha, Negombo, Kurunegala, and Kalutara. Ten locations were selected for sample collection from each of the above-mentioned areas.

The organic materials collected for this study were (a) animal manures, (farm yard manure, goat manure, pig manure, poultry manure of broilers and layers), (b) other dead materials (biogas residues, sewage sludge and compost, which were made with cattle manure and green manure) and (c) green manures (acacia, calopagonium, centrosema, gliricidia and pueraria).

The nutrient contents of these organic materials were determined using standard analytical procedures. The chemical parameters determined were total $\mathrm{N}, \mathrm{P}, \mathrm{K}, \mathrm{Mg}, \mathrm{Ca}, \mathrm{Na}, \mathrm{Fe}, \mathrm{Mn}, \mathrm{Cu}, \mathrm{Zn}, \mathrm{Cd}, \mathrm{B}$ using methods described by Cresser and Parson, 1979, ammonium $\mathrm{N}$ and nitrate $\mathrm{N}$ using methods described by Marr and Cresser, 1983 and organic carbon using methods described by Nelson and Sommers, 1975.

\section{RESULTS AND DISCUSSION}

Nutrient contents of the organic materials tested are given in Tables 1 and 2. Goat manure and fresh foliage of gliricidia contained higher content of $N$ than the other materials. Nitrogen content was higher in broiler litter than in layer litter. Sewage sludge had the lowest $N$ content. The highest $P$ content was found in poultry manure. The $\mathrm{K}$ content was high in green materials as well as in poultry and goat manures, while Mg content was high in FYM and biogas residues (Table 1). Similar trends of macro nutrient status of organic materials have been reported by others (Parr and Colacicco, 1987; Maraikar and Amarasiri, 1988).

Table 2 shows that all the organic materials contain appreciable amounts of heavy metals such as $\mathrm{Fe}, \mathrm{Mn}, \mathrm{Cu}, \mathrm{Zn}, \mathrm{B}$, and $\mathrm{Cd}$. Animal dung contain higher proportions of $\mathrm{Cd}, \mathrm{Zn}, \mathrm{Cu}, \mathrm{Mn}$, and $\mathrm{Fe}$ compared to plant materials and compost. Several publications have reported on the distribution of heavy metals in organic wastes from different countries (Sommers, 1976; Parr and Colacicco, 1987). It is also noteworthy that B content in plant materials such as gliricidia, acacia, pueraria, calapogonium, and centrosema are higher than in animal manures. 
Table 1 : $\quad$ Total macro nutrient content (oven dry basis) - (\%)

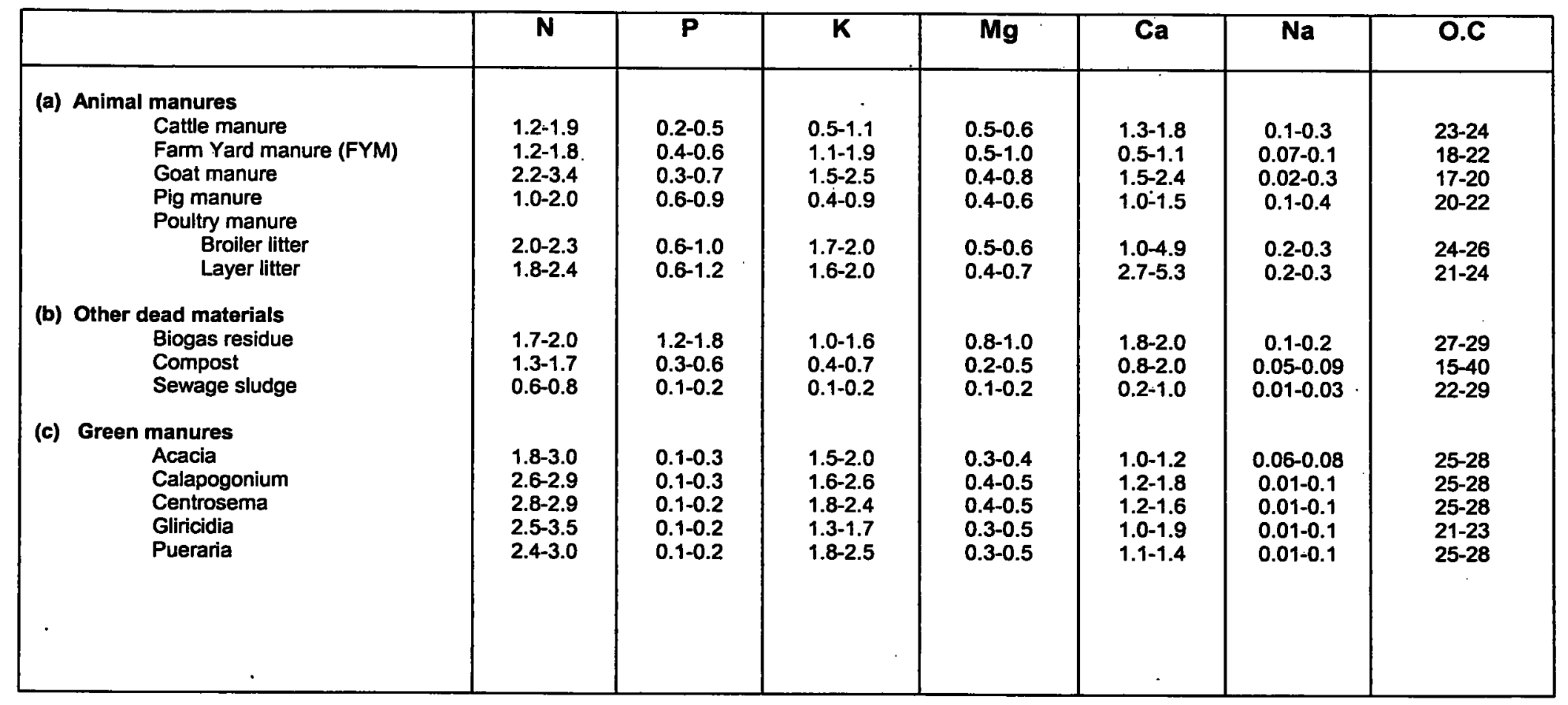


Table 2 : $\quad$ Total micro nutrient content (oven dry basis) - (mg/kg)

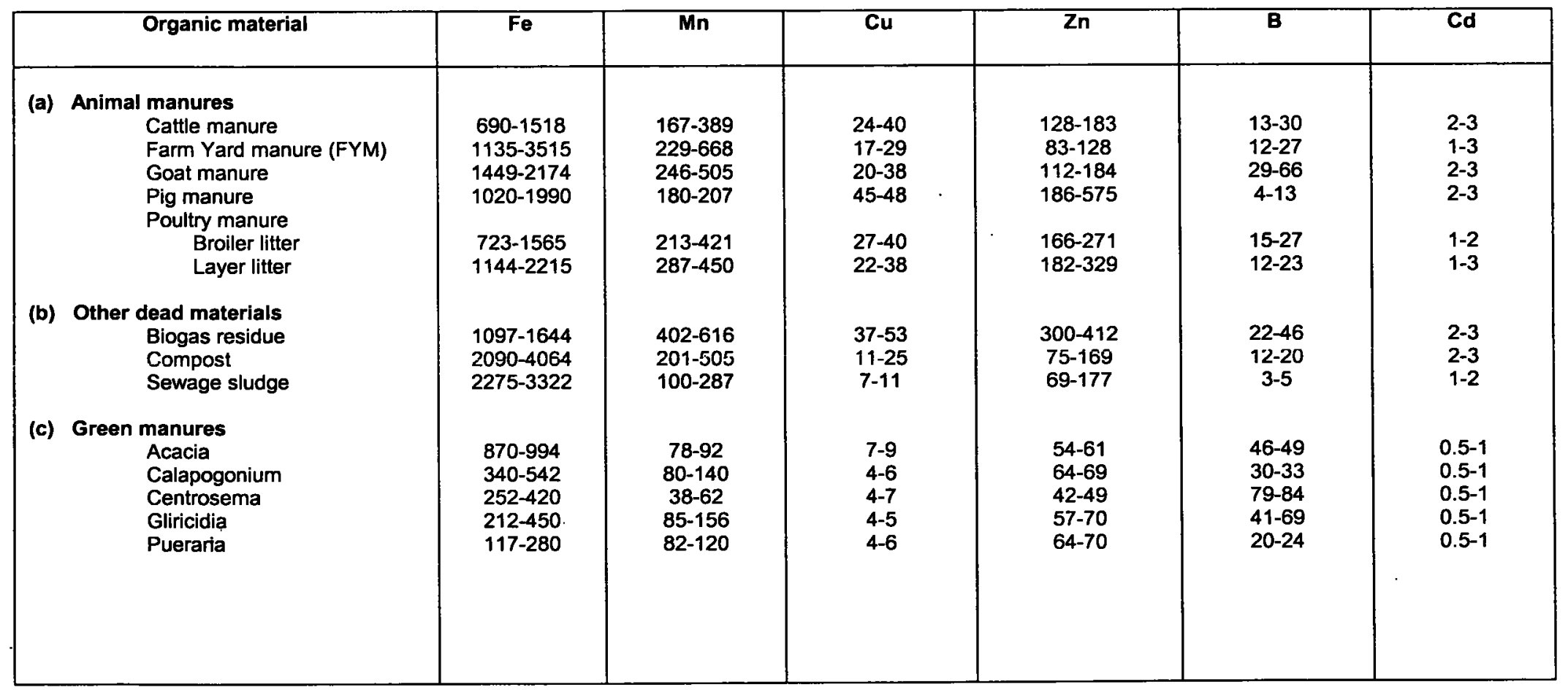


The potential of organic materials to improve the quality of agricultural soil has been discussed elsewhere (Tennakoon et al., 1995). Data presented in this paper show that both plant materials and animal manure have considerable amounts of plant nutrients. Thus continual applications of these organic manures will not only supply plant nutrients but also enrich agricultural soils. However, the possible accumulation of $\mathrm{Cd}, \mathrm{Zn}$, and $\mathrm{Cu}$ needs to be further investigated. These metals enter the soil as ions or chelates following decomposition of organic matter. Research publications on accumulation of heavy metals in soil and its subsequent effect on crops in the context of Sri Lanka are scarce.

The $\mathrm{C} / \mathrm{N}$ ratio of some selected organic materials has been shown to be in the range of 1:1 - 15:1 (Brady, 1994). However, compost samples showed a higher value of $\mathrm{C} / \mathrm{N}$ ratio such as 11:1 - 23:1. (Brady, 1994). Those with lower $\mathrm{C} / \mathrm{N}$ ratio are readily decomposed by microbes, which eliminate the need to supplement with $N$ sources to enhance degradation (Brady, 1994). However, materials, which have a $\mathrm{C} / \mathrm{N}$ ratio of 20 , may need supplementation of $\mathrm{N}$ to enhance the decomposition rate.

Any of the organic materials tested may be used as a nutrient source for coconut. On the basis that the entire $\mathrm{N}$ requirement of coconut is supplied by applying the appropriate quantity of organic manure, the requirement of other nutrients, to be supplied as chemical fertilizer, can be calculated. Such estimates for some selected organic manures are given in Table 3. Based on nutrient content of animal manure and green manure recommended for adult coconut palm by Coconut Research Institute are given in Table 3.

The inorganic fertilizer recommendation for adult coconut palm is $3 \mathrm{~kg}$ of Adult Palm Mixture and $1 \mathrm{~kg}$ of dolomite per palm per year. The cost of the fertilizer is about 46 rupees (According to the fertilizer prices of year 2001). However, most of the small holders can either produce organic manures by composting the wastes or obtain animal husbandry wastes in the home gardens. The farmers those who are utilizing home made organic manures can substitute the necessary nitrogen, phosphorus, potassium and magnesium nutrient components completely or partially for their palms. These farmers will have to pay only for the muriate of potash (Table 4). 
Table 3: $\quad$ Additional $P, K$ and $M g$ fertilizer requirements for an adult coconut palm when organic manure is used to supply the full requirement of $\mathbf{N}$

\begin{tabular}{|c|c|c|c|c|}
\hline \multirow[b]{2}{*}{ Soil type } & \multirow{2}{*}{$\begin{array}{l}\text { Quantity of } \\
\text { organic manure } \\
\text { to supply } N(\mathrm{Kg})\end{array}$} & \multicolumn{3}{|c|}{ Quantity of chemical fertilizer (g) } \\
\hline & & $\begin{array}{c}\text { Saphos } \\
\text { phosphate }\end{array}$ & $\begin{array}{l}\text { Muriate of } \\
\text { potash }\end{array}$ & Dolomite \\
\hline $\begin{array}{l}\text { Lateritic or quartzitic gravelly } \\
\text { loams, sands in coastal areas } \\
\text { and river flood plains } \\
\text { Deep, reddish or yellowish } \\
\text { loams in coastal areas, deep } \\
\text { colluvial loams at foothills, } \\
\text { alluvial loams in flood plains }\end{array}$ & $\begin{array}{c}\text { Cattle manure } \\
\text { (moisture 20- } \\
30 \% \text { ) } \\
30 \\
\\
20\end{array}$ & - & 1250 & $\begin{array}{l}-- \\
\text {-- }\end{array}$ \\
\hline $\begin{array}{l}\text { Lateritic or quartzitic gravelly } \\
\text { loams, sands in coastal areas } \\
\text { and river flood plains } \\
\text { Deep, reddish or yellowish } \\
\text { loams in coastal areas, deep } \\
\text { colluvial loams at foothills, } \\
\text { alluvial loams in flood plains }\end{array}$ & $\begin{array}{c}\text { Goat manure } \\
\text { (moisture 20- } \\
25 \% \text { ) } \\
25 \\
\\
20 \\
\end{array}$ & -- & 800 & -- \\
\hline $\begin{array}{l}\text { Lateritic or quartitic gravelly } \\
\text { loams, sands in coastal areas } \\
\text { and river flood plains } \\
\text { Deep, reddish or yellowish } \\
\text { loams in coastal areas, deep } \\
\text { colluvial loams at foothills, } \\
\text { alluvial loams in flood plains }\end{array}$ & 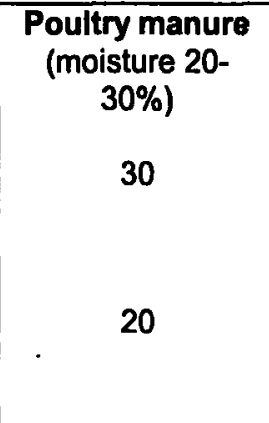 & - & 650 & - \\
\hline $\begin{array}{l}\text { Lateritic or quartzitic gravelly } \\
\text { loams, sands in coastal areas } \\
\text { and river flood plains } \\
\text { Deep, reddish or yellowish } \\
\text { loams in coastal areas, deep } \\
\text { colluvial loams at foothills, } \\
\text { alluvial loams in flood plains }\end{array}$ & $\begin{array}{c}\text { Gliricidia } \\
\text { (moisture 60- } \\
70 \% \text { ) } \\
30 \\
\\
20\end{array}$ & 350 & 1000 & 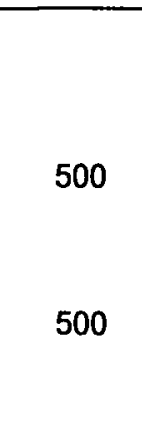 \\
\hline
\end{tabular}


Table 4: Cost of recommended inorganic and organic fertilizer application/palm/year (Purchased and home made)

\begin{tabular}{|l|c|c|c|c|c|}
\hline Name of fertilizer & $\begin{array}{c}\text { Quantity } \\
\text { (kg) }\end{array}$ & $\begin{array}{c}\text { Cost (Rs) } \\
\text { (Purchased) } \\
\text { (Inorganic \& } \\
\text { Organic) }\end{array}$ & $\begin{array}{c}\text { Cost (RS.) } \\
\text { (Home made) } \\
\text { (Organic) }\end{array}$ & $\begin{array}{c}\text { Cost (Rs.) } \\
\text { Reduction } \\
\text { Purchased }\end{array}$ & $\begin{array}{c}\text { Cost (Rs.) } \\
\text { Reduction } \\
\text { Home } \\
\text { made }\end{array}$ \\
\hline $\begin{array}{l}\text { Adult Palm Mixture } \\
\text { Dalomite }\end{array}$ & 3 & 46 & - & 0 & 0 \\
\hline $\begin{array}{l}\text { Cattle Manure } \\
\text { Muriate of Potash } \\
\text { (M OP) }\end{array}$ & 1.2 & 54 & 23.90 & -8 & +22.10 \\
\hline $\begin{array}{l}\text { Goat manure } \\
\text { Muriale of Potash } \\
\text { (M O P) }\end{array}$ & 0.8 & 41 & 15.95 & +5 & +30.05 \\
\hline $\begin{array}{l}\text { Poultry Manure } \\
\text { Muriale of Potash } \\
\text { (M OP) }\end{array}$ & 0.75 & 45 & 14.95 & +1 & +31.05 \\
\hline
\end{tabular}

If $30 \mathrm{~kg}$ of cattle manure plus $1.2 \mathrm{~kg}$ of M.O.P is used the cost will be 23.90 rupees per palm/year. If $25 \mathrm{~kg}$ of goat manure and $0.8 \mathrm{~kg}$ of M.O.P is used the cost is 15.95 rupees. In the case of poultry manure $30 \mathrm{~kg}$ and 0.75 M.O.P the cost will be about 14.95 rupees. If the organic manures are purchased at the rate of $1 \mathrm{~kg}$ per 1 rupee, then the cost will be about rupees 54,41 and 45 respectively.

\section{CONCLUSION}

Locally available organic materials contain low cost amounts of macro and micro nutrients and these materials could be used as low cost sources of nutrients for coconut. 


\section{REFERENCES}

Brady, N.C. 1994. The Nature and Properties of soils $10^{\text {th }}$ edition. Macmillan Publishing Company New York.

Cresser, M.S. and Parson, T.W. 1929. Sulphuric perchloric acid digestion of plant materials for the determination of $\mathrm{N}, \mathrm{P}, \mathrm{K}, \mathrm{Ca} \& \mathrm{Mg}$. Analytica Chimisa Acta 109,431-436.

Flaig, W. 1984. Soil organic matter as a source of nutrients. In : Organic matter and rice. pp 73-92. International Rice Research Institute, Manila, Philippines.

Maraikar, S. and Amarasiri, S.L. 1988. Plant nutrient content of animal wastes. Tropical Agriculturist 144, 79-87.

Marr, I.L and Cressor, M.S. 1983. Environmental Chemical Analysis. International Text Book Company, New York p 166-167.

Nelson, D.W and Sommers, L.E 1975. A rapid and accurate method for estimating organic carbon in soil. Proceeding of the Indiana Academy of Science, 84,456462.

Parr, J.F. and Colacicco, D. 1987. Organic materials as alternative nutrient sources In: Energy in plant nutrition and pest control (ed.Helsel, Z.R.) pp 81-99. Elesevier Science Publishers, B. V. Amasterdam, The Netherlands.

Sommers, L.E. 1977. Chemical composition of sewage sludges and analysis of their potential use as fertilizers. Journal of Environmental Quality 6, (2) 225-232.

Tennakoon, N.A. 1990. Goat manure as a soil 'ameliorant' and yield 'stimulant' in coconut. COCOS. The Coconut Research Institute of Sri Lanka 8,26-32.

Tennakoon, N.A., Mahindapala, R \& Widanapathirana, S.1995. Effect of application of organic manure on the quality of coconut soils. Journal of the Natural Science Committee of Sri Lanka 23 (4), 171-182. 